\title{
Analysis of environmental factors affecting the quality of teacher's life of public schools from Umuarama
}

\author{
Bruna Evellyn Costa ${ }^{\mathrm{a}}$, Nicéia Luzia Selete Silva ${ }^{\mathrm{b}}$ \\ ${ }^{a}$ Universidade Paranaense,UNIPAR, Specialist in Ergonomics and Occupational Health, Address: Dos Pampas \\ Street, 2273, ZIP CODE: 87505-020, Brazil, (44) 3639-0254 / (44) 99223493, bruna evellyn costa@hotmail.com \\ ${ }^{b}$ Universidade Paranaense, UNIPAR, Specialist in Ergonomics and Occupational Health, Address: São Paulo \\ Avenue, 4864, ZIP CODE: 87501-420,Brazil, (44)3624-7740 /(44)8439-1583,niceia@unipar.br
}

\begin{abstract}
In this study valued 100 public school teachers statewide Umuarama-Pr, through Maslach Burnout Inventory (MBI) and also a socio-demographic questionnaire with objective factors to analyze the work environment that affect the quality of life for teachers public schools in Umuarama. The results indicated that teachers age between 20 and 30 years show high index of emotional exhaustion. Between 30 and 40 years have a low average emotional exhaustion and depersonalization and an average professional achievement. Teachers between 40 and 50 years of aged had resulted in the average within the fields Burnout Inventory with a group that's worrying, because it is the limit in all items that characterize the burnout syndrome. Already in the professionals aged between 50 and 60 years have seen high levels of emotional exhaustion, low depersonalization and low professional achievement, this group, which probably already had some of these symptoms are only now been identified. This shows how is the quality of life of the group of teachers surveyed, and indicates the need for action to change this situation and find solutions. A suggestion of this work is to build a center for psychological support for teachers to learn to handle everyday situations.
\end{abstract}

Keywords: burnout, teachers, quality of life.

\section{Introduction}

Quality of life is an important issue for all workers, because by means of preventive care with physical, mental and emotional health of employees, organizations meet part of their productive and social responsibility. With this in mind, and considering that teachers are professionals in education and who are faced with a socio-cultural development of pupils other than a few years ago, and yet, that affect their quality of life in the classroom (work), this study aimed to apply the methodology Maslach Burnout Inventory (MBI) to assess the conditions of life. In the work of teachers of public schools teaching from Umuarama-PR.

The WHO defines quality of life as "an individual's perception of their position in life in the cultural context and value system in which they live and in relation to their goals, expectations, desires and concerns" [8].

There was the attempt to understand this class of workers who contributed so much to the formation and transformation of society. Question their quality of life is necessary to all and the important is that "people feel better psychologically, have good physical condition and feel socially integrated and functionally competent" [9]. This means that individuals, while preserving their physical health, should feel productive to maintain their mental health.

According to[6], Burnout from English burn = burn, out $=$ out, i.e burn out is a syndrome that affects the worker, when he no longer sees any sense in their work; mainly affects the worker in direct contact with the user, and in this case the teacher is the worker and the student is the user. 
The way this syndrome manifests itself and happens is characterized a lot with the teachers workers and Maslach [quoted in 16] says that "unlike the acute stress reactions that are related to critical incidents and specific, Burnout is a cumulative reaction to occupational stressors continued." This is related to working conditions for holding a direct or close contact with others in which teachers fits, because they relates more closely to their students.

When the teacher wants their students to learn, can create an emotional relationship of affection. "In other words, the role of the teacher ends up establishing a game of seduction, where he will gain the attention and arouse the interest of the student to the knowledge that he wants to address." [6]. Already [11], conceptualizes it as a syndrome characterized by physical exhaustion, mental and emotional as a result of stressful and excessive work. It is a clinical condition resulting from the poor man's adaptation to his work. This collaboration with the teaching of student learning, because it perceives the teacher's concern and involvement with their difficulty. However, the involvement that even helps the novice can harm the health of the master who is related to a number of individuals / users and, therefore, with the problems of them all.

The causes and symptoms are not universal. Depending on the characteristics of the person and the circumstances in which it is found, the extent and manifestations are different. [1]. It is important to note that different teachers with the same working conditions may have different reactions to the environment and individuals, who are among influential variables exist, one of the most outstanding.

Burnout syndrome is made according to [13], in three dimensions: Emotional Exhaustion: Lack of energy, feelings of emotional exhaustion. Depersonalization: Establish interpersonal relationships so cool, featuring emotional insensitivity. Low personal accomplishment: Negative self-evaluation, lack of motivation to work.

Often the Burnout syndrome may be mistaken simply as a stress only. To [11] stress is not always harmful, but when it becomes prolonged is one of the causes of the exhaustion that can lead to Burnout.

"Occupational stress can be understood as situations in which people perceive their work environment as threatening to their needs for professional and personal fulfillment, and / or their physical and mental health, impairing its interaction with the work and the work environment, as this environment contains excessive demands it, or does not contain adequate resources to face such situations. "[11].

Whereas the stress alone affects the individual and not necessarily affect him as worker, the Burnout Syndrome explains the relationship of stress with work. According to [4] "stress is a process, does not appear magically, its development depends on the strength of each person, their personality, their way to accept things that happen." Linking this definition with França definition, it is clear that stress at work can occur according to the variables of the personality of each individual and can affect your health when you react the way the problem or conflict situations is not sanitizing or not results in a solution that pleases him.

Often the teacher is not prepared to take criticism and complaints, and just seeing the work as an obligation to be fulfilled, that is why [10] says "Work should not be sacrifice or suffering. Work is to accept responsibility and also leave room for selfcriticism for failures. The pleasure comes from feelings of success, moral evaluation, compliance responsibilities".

Most of the time the teacher works with various types of clientele, from students with divorced parents, drug dealers, prostitutes, students that are designed with the grandparents, families with different culture, education and social level. Also faced with the envy of fellow professional direction of the pressure that requires both in results and notes in the reduction of absences.

Identifying Burnout occurs in some professional aspects, as explained [3] and may have losses in their lesson planning, becoming less frequent and careful. Feeling less sympathy for the students, may feel frustrated by the problems occurring in the classroom or the lack of progress of students. Feelings of hostility with the school board and families of students as well as developing a negative image with the professional relationship, being self deprecating and sorry to have entered the profession.

"Burnout occurs in highly motivated employees who react to stress at work working until further collapse". [6].

"The treatment of Burnout syndrome involves psychotherapy, pharmacological treatment and psychosocial interventions. However, the intensity 
of each prescription of a therapeutic resources depends on the severity and specificity of each case". (ICD-10 Z73.0) [2].

Item XII table of Mental and Behavioral Disorders Related with Work (Group V of the International Classification of Diseases - ICD-10) cites the "Feeling of Being Done" (BURN-OUT SYNDROME OR BURNOUT SYNDROME) than in icd-10 receive an code Z73. 0 and talks about the diagnosis of Burnout syndrome:

"The diagnosis of a case of Burnout syndrome should be approached as a sentinel event and indicate the status of research work, in order to evaluate the role of work organization in determining the symptomatology. Interventions may be indicated in the work organization, as well as measures of support group where the affected workers came". [2]

[7] Stated that the work is not always possible professional achievement. This statement seems contrary to the concept given by the Codo to Burnout Syndrome, which determines the occurrence motivated employees. It gets the idea that a professional has motivated more prone to this syndrome by frustration that the work may cause you, or activity that is not wanted, or because of conflicts, or for physical working conditions, or any another variable that represents a negativity in their work activities and which may generate disappointment and dissatisfaction at work, resulting in a disease.

\subsection{General objective}

Analyze the work environment factors that affect the quality of life of public school teachers statewide from Umuarama.

\subsection{Specific objectives}

Identify the main environmental factors that influence the quality of life of teachers from teacherpupil-school relationship.

Relate environmental factors to teachers' absences and retrofits to work.

To assess the influence of environmental factors identified in the quality of life of public school teachers statewide from Umuarama.

\subsection{Methodology}

\subsubsection{Participants}

The sample of this research was composed of elementary school teachers from 5th to 8th grade and High School public schools of Umuarama-Pr.

The sample was 100 teachers of both sexes, aged between 20 and 60, all regular education.

\subsubsection{Instruments}

Two questionnaires were used, the first sociodemographic addressing issues such as gender, age, working time, workload, relationship with school and student peers, and so on. And another survey found that the presence or absence of Burnout syndrome using the Maslach Burnout Inventory (MBI).

This current version consists of 22 items with application of Likert scale (in the form of assertions) is assigned degrees of intensity ranging from 0 to 6 , as follows: zero (never), 1 (sometimes for years), 2 (once a month), 3 (sometimes for months), 4 (once a week), 5 (a few times a week) and 6 (every day).

It consists of three sub-scales: emotional exhaustion, depersonalization and personal accomplishment. The "emotional exhaustion" is composed of nine questions $(1,2,3,6,8,13,14,16$ and 20):

The "depersonalization", consisting of 5 items (5, 10, 11, 15 and 22); And finally the "personal realization", which consists of 8 questions $(4,7,9$, $12,17,18,19$ and 21).

\subsubsection{Procedures}

The Teachers Union Retirees of Parana (APP) provided for teachers to participate by contacting the schools, from this time enabled the research to be performed. The group was divided by age group and the participants signed a consent form for participation in research and then in possession of the questionnaires responded.

The data collected by questionnaire of Burnout Inventory were entered into a spreadsheet that provides a numerical result (statistical) and allows analysis of the domains from this inventory.

The socio-demographic questionnaire was also tabulated on a spreadsheet to generate comparative data to results of the survey Burnout. Finally we proceeded to an analysis of information, as well as his account.

\section{Results}


As discussed above, the Burnout Inventory has three areas in his theorizing that are professional exhaustion, depersonalization, and professional achievement. In each area the individual can get a result different from the other, but to compare these individual results may lead to the conclusion that a professional is or not with the Burnout syndrome. It stands out in this case the field of depersonalization, which given its characteristics, may be the biggest indicator of the presence of the syndrome in the life of a professional who works closely with the user.

For data tabulation and comparison of results from these fields it was used the following dimension table:

Table 1

Dimensions of the areas of inventory of Burnout Syndrome.

\begin{tabular}{lccc}
\hline & \multicolumn{3}{c}{ Domains } \\
& $\begin{array}{c}\text { Emotional } \\
\text { exhaustion }\end{array}$ & Despersonalization & $\begin{array}{c}\text { Profissional } \\
\text { realization }\end{array}$ \\
\hline Hight & $\geq 27$ & $\geq 13$ & $\leq 31$ \\
Moderate & 17 a 26 & 7 a 17 & 32 a 38 \\
Low & $\leq 16$ & $\leq 6$ & $\geq 39$ \\
\hline
\end{tabular}

Source: TEMPSKI, P. Class Material of expertise in ergonomics -

UNIPAR, 2010

Table 2

Values of the media in comparison to the domains related to the age of 20 to 30 years for results of Burnout.

\begin{tabular}{llll}
\hline & EE & DE & RP \\
\hline Medium & 28,375 & 6,75 & 33,2 \\
\hline $\begin{array}{l}\text { Standard } \\
\text { deviation }\end{array}$ & 12,45191 & 5,579725 & 8,719436 \\
\hline Median & 27,5 & 4,5 & 33 \\
\hline Minimum & 7 & 0 & 14 \\
\hline Maximum & 52 & 17 & 48 \\
\hline Percentile 25 & 21 & 2,5 & 28,5 \\
\hline Percentile 75 & 38 & 11,25 & 39 \\
\hline
\end{tabular}

With regard to data calculated from the Burnout Syndrome, for the group aged between 20 and 30 years (Table 2), the teachers in this age group are at a high level of emotional exhaustion represented by the value of 28.375 points, which compared with the domains table is found that are above the value considered high $(\geq 27)$. The depersonalization reached 6.75 , and in relation to the domains table that is $\leq 6$ considers this low value, which is good considering that the average depersonalization already requires high care and can characterize the Burnout syndrome. The professional achievement that shows with 33.2 , and this compared to domain is in average level of between 32 and 38.

Table 3

Values of the media in comparison to the domains related to the age of 30 to 40 years for results of Burnout.

\begin{tabular}{llll}
\hline & EE & DE & RP \\
\hline Medium & 22,8 & 5,608696 & 36,95833 \\
\hline $\begin{array}{l}\text { Standard } \\
\text { deviation }\end{array}$ & 11,82511 & 4,821723 & 7,074013 \\
\hline Median & 24 & 5 & 38,5 \\
\hline Minimum & 0 & 0 & 24 \\
\hline Maximum & 46 & 17 & 48 \\
\hline Percentile 25 & 12 & 2,5 & 32,25 \\
\hline Percentile 75 & 32 & 6 & 42,5 \\
\hline
\end{tabular}

Those who have the age between 30 and 40 years (Table 3) show a value for emotional exhaustion of 22.8 which means they are on average (between 17 and 26), as pointing the need for care since the average may be indicative a sense of evolution in the high level of emotional exhaustion. Also in this section, and aggravating the situation, it is observed that the points obtained are closer to the limit of 26 than the beginning of this size that are 17 points. Depersonalization obtained a value of 5.6 as compared to the area shown low, because this dimension starts at values $\leq 6$. Since job satisfaction resulted in 36.9, compared to areas that are hanging in the middle to high, since this size varies between 32 and 38 .

Table 4

Values of the media in comparison to the domains related to the age of 40 to 50 years for results of Burnout.

\begin{tabular}{llll}
\hline & \multicolumn{1}{c}{ EE } & \multicolumn{1}{c}{ DE } & RP \\
\hline Medium & 26,34483 & 7,433333 & 33,06897 \\
\hline $\begin{array}{l}\text { Standard } \\
\text { deviation }\end{array}$ & 14,43279 & 6,54261 & 7,299369 \\
\hline Median & 26 & 6 & 33 \\
\hline Minimum & 2 & 0 & 16 \\
\hline Maximum & 54 & 22 & 47 \\
\hline Percentile 25 & 16 & 2,25 & 28 \\
\hline Percentile 75 & 37 & 11 & 39 \\
\hline
\end{tabular}

Individuals between 40 and 50 years (Table 4) are about average for the emergence of emotional exhaustion, but go to high exhaustion because the value was 26.34 which begins beyond the limit of the average size of this domain. For depersonalization the value achieved was 7.43, which represents an average value that ranges 
between 7 and 17, so closer to downtown, which shows an opportune time for a corrective and preventive action to avoid arriving at high depersonalization and Burnout syndrome develop. And job satisfaction is at 32.06 , meaning that they are moderately performed professionally.

Table 5

Values of the media in comparison to the domains related to the age of 50 to 60 years for results of Burnout.

\begin{tabular}{lrrr}
\hline & EE & DE & \multicolumn{1}{l}{ RP } \\
\hline Medium & 27,70833 & 7,96 & 39,26087 \\
\hline $\begin{array}{l}\text { Standard } \\
\text { deviation }\end{array}$ & 15,62183 & 8,203048 & 6,936186 \\
\hline Median & 29 & 6 & 39 \\
\hline Minimum & 0 & 0 & 22 \\
\hline Maximum & 51 & 29 & 48 \\
\hline Percentile 25 & 13,75 & 1 & 36 \\
\hline Percentile 75 & 39,75 & 11 & 45 \\
\hline
\end{tabular}

Who has 50 to 60 years of age (Table 5) have a high degree of emotional exhaustion which is 27.70 , and there is this dimension of this area a quantity $\geq$ 27 points. Depersonalization is seen in table 7.96 that this domain represents the average ranging from 7 to 17 . There is also a low job satisfaction were obtained from a 39.26 in the comparison table and this dimension is $\geq 39$. This is the most affected age group, since the values obtained from this study found two areas with the greatest dimensions of the extreme negative, that is, high emotional exhaustion and low professional. Compounding, depersonalization enters a zone that requires care, because the ideal would be to maintain low depersonalization, and in this age group it is as median.

The results of the socio-demographic research for the onset of exhaustion, depersonalization, and professional achievement compares female and male, length of service, workload, age and average students (users) with whom teachers works.

So, the graphics are organized into a female and male in a ratio of $79 \%$ female to $21 \%$ male, as shown in Figure 1.

Teachers from 20 to 30 years old has representation of $17 \%$, between 30 and 40 years old $26 \%$, between 40 and 50 years $32 \%$, and from 50 to 60 years $25 \%$, as shown in Figure 2.

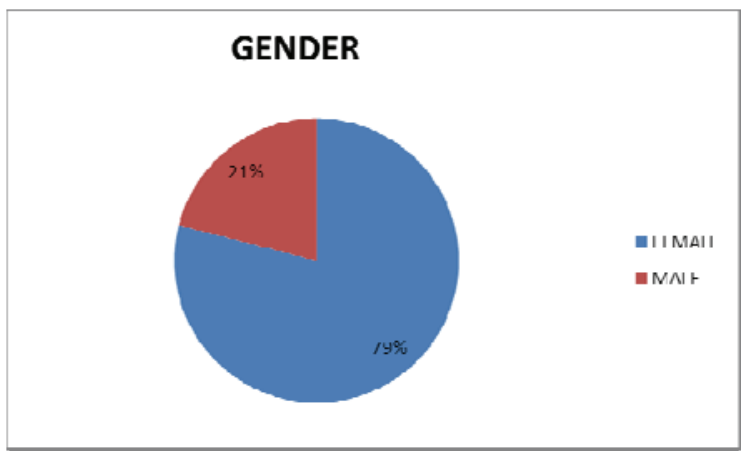

Fig. 1 shows percentile female and male who works in regular education of public schools of Umuarama-Pr.

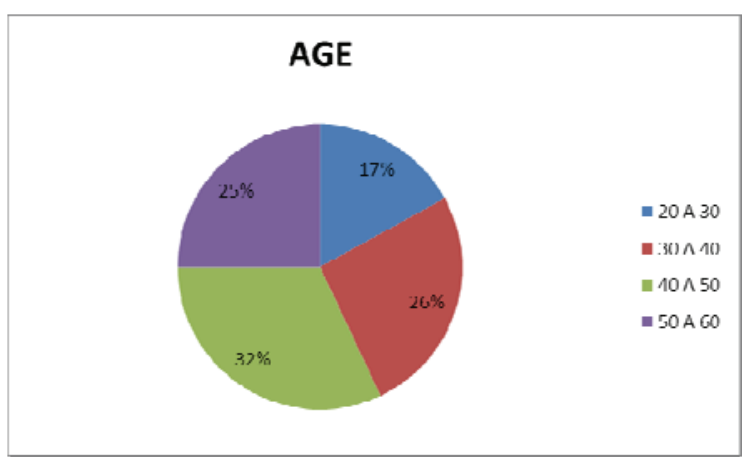

Fig. 2 shows age percentile of the surveyed teachers who work in the regular education of Umuarama-Pr.

On the other hand the weekly workload of teachers revealed that $51 \%$ have a load-hours of work between 40 and 60 hours weekly, 41\% works between 20 and 39 hours weekly and $8 \%$ works less than 20 hours, shown in Figure 3.

Figure 4 reveals that $37 \%$ of teachers surveyed worked for over 20 years, $19 \%$ works between 15 and 20 years, $12 \%$ works between 10 and 15 years, $8 \%$ works from 6 to 9 years, $10 \%$ works between 3 and 5 years, $9 \%$ works between 1 and 2 years and $5 \%$ works less than one year. This is related to age since there was the identification of a situation that requires caution in the range between 50 and 60 years old, who are the majority of those working more than 20 years. 


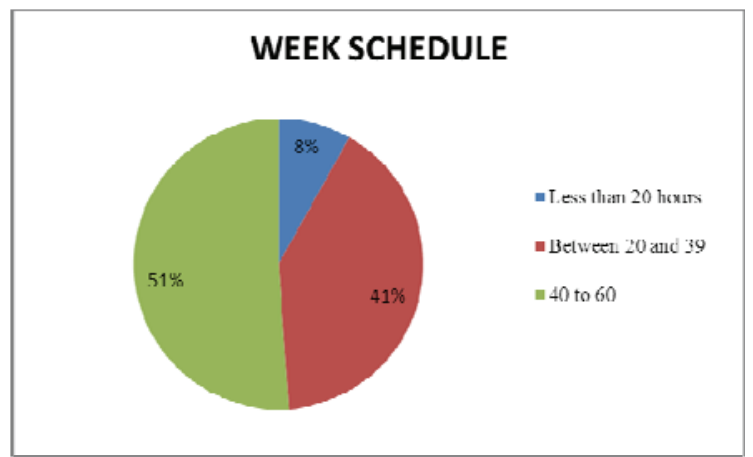

Fig. 3 shows percentile of weekly working hours of teachers in regular education of Umuarama-Pr.

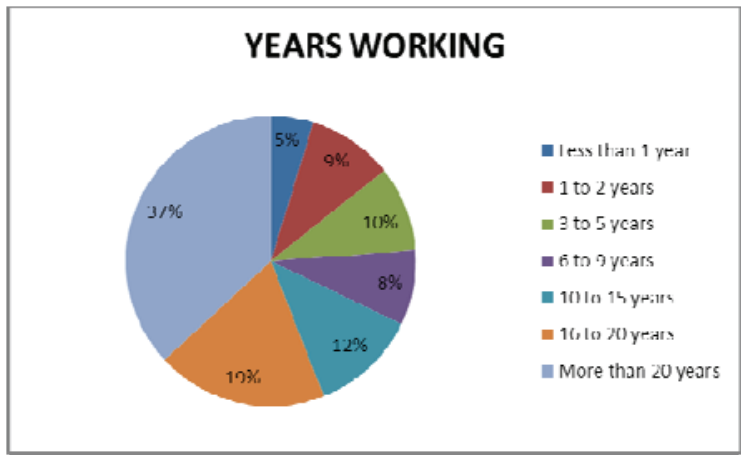

Fig. 4 shows percentile of years of work of teachers in regular education of Umuarama-Pr.

\section{Discussion}

The result shows that teachers between 20 and 30 years old have high levels of emotional exhaustion, it refers to lack of experience. However, this lack of experience that exists among these professionals can not confirm that they are burnout, but with symptoms that predispose to the appearance. This result is confirmed by [5] research and [3] indicating that younger people have high level of burnout. It was observed here that women are more predisposed to emotional exhaustion, and this age group of teachers surveyed consists of mostly women.

The socio-demographic survey of this study also shows that teachers work with a large contact with their students, because reveals that $68 \%$ works with 40 students on average. Still, one must remember that this is a number for a class and, in fact, the teacher works in several other rooms of equal or greater number of students, taking any type of contact and care with them. The number of students served daily is an explanation of the emergence of emotional exhaustion, a result explained by [14].

As teachers between 30 and 40 years old are in the average limit of emotional exhaustion then the concern may be less, since the value obtained by depersonalization is below and they are moderately performed professionally.

The interviewees between 40 and 50 years old are in an average case for the three areas, namely: emotional exhaustion, depersonalization, and professional achievement. This is a group to worry about since the results show and some researchs confirm that the symptom of burnout could be present when young and has come when they are already at an age of professional experience. In addition as [17] say, national and international studies have shown that men generally have higher scores for symptoms of depersonalization, whereas women tend to have higher rates of emotional exhaustion. And as the number of male teachers is mostly in this age group, this confirms to lower negative scores in emotional exhaustion.

Professionals between 50 and 60 years old are already showing a high level of emotional exhaustion and low professional satisfaction. It is shown that the professional experience refers to the question that the teachings of today are not the same as before, since teachers are suffering from aggression, even though relatively low compared to negative value. The survey shows that $54 \%$ of respondents did not suffer any verbal abuse while $46 \%$ said yes, suffered some kind of verbal abuse by students. One of the explanations given in the survey conducted by [3] is that the bad behavior of students is associated with decreased in job satisfaction, it makes that teachers have a sense of lack of achievement. But the research of [12] reports that teachers with more experience and age are less vulnerable to the onset of burnout, where there is evidence that they can manage situations in the classroom through their acquired skills to the right time .

The remarkable thing about the research that 58\% of teachers surveyed say they have or had health problems as a result of being a teacher, and $42 \%$ denied any health problems. The problems are the most diverse where the most frequently reported were headache and vocal problems.

On the websites of the schools surveyed we found 10 teachers away for health care, this number is explained because these teachers work in two or more schools, which adds to the routine of home 
since the majority are women and, in addition to teaching work at home, one more aggravating for your health. They stood out with high percentage values clean the house, preparing lunch and washing clothes.

About teachers readapted there are two types: those temporary, that after a period away from returning to their teacher routine and others who depart for a certain time and then are re-adapted, because they are definitely considered unfit function of teachers and will work in computer lab, office, operator or end up being assistants - "errand boy" from schools. All kinds of diseases are reported by them to justify their rehabilitation, these informations was obtained from the teachers' syndicate from Umuarama APP, which is much interested in the search result, since something was not done, but is charged by teachers as is commented on by the president of the Syndicate here in Umuarama-Pr.

\section{Conclusion}

Using the results of this survey it was found that there are factors for the development of burnout syndrome in the public school teachers from Umuarama teaching, for example, the age of the teacher. However, this research showed that not only young people, for his inexperience, showed worrying symptoms, but also the most experienced, linking the idea that since the beginning of their age in adulthood had some symptoms, but only now it was manifest. In this sense, excessive working hours is a contributing factor.

It is noteworthy that contribute to the onset of symptoms that lead to burnout syndrome demand of students in class, so direct contact with an excessive number of users for a prolonged period, which is linked to bad behavior and lack of respect for the teaching, and the daily routine of not working only in schools but in their homes resulting in an accumulation of functions, consistent with an excess workload.

Considering the factors that stood out as the cause of burnout syndrome, its prevention requires educational and therapeutic at the individual, group, organizational and social [18]. Add here the actions of government in relation to educational policy regarding, for example, number of students in the classroom and hours worked in direct contact with the user. "The prevention of stress and burnout syndrome requires the reformulation of individual and collective mechanisms of workers and often involve a redefinition of concepts and values" [19].

As a suggestion resulting from this study, it was proposed the creation of a support center containing a team of psychologists, for monitoring and assistance, both for those who had some indication of the burnout syndrome, as for the others to avoid or minimize possible emergence of the syndrome. And thus provide educators a healthy life without work stress.

\section{References}

[1] Benevides-Pereira, A.M.T. A saúde mental de profissionais de saúde mental: uma investigação da personalidade de psicólogos. Maringá: EDUEM, 2001.

[2] Brasil. Organização Pan-Americana da Saúde no Brasil. Doenças relacionadas ao trabalho: manual de procedimentos para os serviços de saúde. Brasília: Ministério da Saúde do Brasil, 2001.

[3] Carlotto, M. S. A síndrome de Burnout e o trabalho docente. Psicologia em estudo. Maringá, vol.7, n.1, jan/jun 2002. Disponível em: http://www.sceilo.br. Acesso em:

[4] Carvalho, A.V. de. Administração de recursos humanos. Biblioteca Pioneira de administração e negócios. São Paulo, v.2. 1995. Disponível em: http://www.faeso.edu.br/horusjr/artigos/Artigo13.pdf. Acesso em: 01 fev. 2010.

[5] Codo W. Educação: carinho e trabalho. Petrópolis: Ed. Vozes, 1999

[6] (org.). Educação, carinho e trabalho: Burnout, a síndrome da desistência do educador, que pode levar à falência da educação. Rio de Janeiro: Vozes, 2002.

[7] Dejours, C. A loucura do trabalho. Cortez-Oboré: São Paulo, 1992.

[8] Fleck, M. P. A. Versão em português dos instrumentos de avaliação de qualidade de vida (WHOQOL) 1998. Grupo de estudos em qualidade de vida do hospital das clínicas do Rio Grande do Sul. Porto Alegre, 2003. Disponível em: http://www.ufrgs.br/psiq/whoqol.html. Acesso em: 06 de maio 2010.

[9] _ . et al. Desenvolvimento da versão em português do instrumento de avaliação de qualidade de vida da OMS (WHOQOL-100). Revista Brasileira Psiquiatria, v.21, n.1, p.19-28, mar. 1999.

[10] Fonseca, C.C.O.P. O adoecer psíquico no trabalho do professor de ensino fundamental e médio da rede pública no Estado de Minas Gerais. 2001. 231p. Dissertação (Mestrado). Universidade Federal de Santa Catarina. Florianópolis: 2001.

[11] França, A.C.L. Stress e trabalho. 2.ed. São Paulo: Atlas, 1999

[12] Levy, G. C. T. M.; NUNES SOBRINHO, F. P.; SOUZA, C. A. A. de. Síndrome de Burnout em professores da rede pública. Produção. 2009, v.19, n.3, pp. 458-465. Disponível em: http://www.scielo.br . Acesso em: $29 \mathrm{de}$ julho de 2010.

[13] Maslach, C.; LEITER, M.P. Trabalho: fonte de prazer ou desgaste? Guia para vencer o estresse na empresa. 
Campinas: Papirus, 1999

[14] Moura E.P.G. Saúde mental e trabalho: esgotamento profissional em professores da rede de ensino particular de Pelotas - RS. 1997. Dissertação (Mestrado). Instituto de Psicologia da Pontifícia Universidade Católica do Rio Grande do Sul. Porto Alegre: 1997.

[15] Paraná. Secretaria de Estado da Educação. Consulta escola. Portal educacional do Estado do Paraná. Disponível: http://www4.pr.gov.br/escolas/listaescolas.jsp acesso: 04/09/10.

[16] Rossi, A. M, et al. (orgs.) Stress e qualidade de vida no trabalho: perspectivas atuais da saúde ocupacional. São Paulo: Atlas, 2005.

[17] Silva, G. N; CARLOTTO, M. S. Síndrome de Burnout: um estudo com professores da rede pública. Revista de Psicologia Escolar e Educacional, v. 7, n. 2, p.145-153, 2003.

[18] Trindade L.L. O estresse laboral da equipe de saúde da família: implicações para saúde do trabalhador. 2007. Dissertação (Mestrado) - Universidade Federal do Rio Grande do Sul, Porto Alegre: 2007.

[19] LAUTERT, L. Síndrome de Burnout entre os trabalhadores da estratégia de saúde da família. Revista Escola de Enfermagem. USP, v.44, n.2, pp. 274-279. 2010. Disponível em: http://www.scielo.br/reeusp . Acesso em: 03 de agosto de 2010 . 